\title{
The Role of Investigator in Applying Diversion to Children in Conflict with the Law in the Jurisdiction of Padang City Police
}

\author{
Andre Dwijaya Saputra; Elwi Danilm; Yoserwan \\ Faculty of Law, Andalas University, Padang, Indonesia
}

http://dx.doi.org/10.18415/ijmmu.v6i5.1113

\begin{abstract}
The objectives of this study are to: 1) find out and analyze the role of investigator of the Women and Child Protection Unit in applying diversion to children in conflict with the law, 2) determine and analyze the implementation of diversion carried out by the Women and Child Protection Unit against children in conflict with law, 3) identify and analyze the obstacles of investigators of the Women and Child Protection Unit in applying diversion to children in conflict with the law. This research employs the sociological juridical method, a research in the discipline of law that is based on the reality that occurs in society where the type of study in this study is specifically descriptive. The results of this study found that: 1) the implementation of diversion in Padang City Police had been going well where there were 14 (fourteen) cases that were successfully resolved through diversion channels throughout 2015-2017, 2) the implementation of diversion in Padang City Police was guided by the Law on the Criminal Justice System for Children (UU SPPA), Secret Telegram of the Head of the Criminal Investigation Agency of the Republic of Indonesia Police TR/1124/XI/2006 and TR/395/DIT,VI/2008, and Government Regulation No. 65 of 2015, 3) in applying the diversion, Padang City Police investigators faced several obstacles such as: the victim felt that his/her rights were not protected because the suspect was given privileges in the legal process and the victim or his/her family considered the law to be biased and favored the suspect. It is the reason for the failure of deliberation regarding diversion. To anticipate this failure, there are a number of suggestions in which human resources in the Children's Criminal Justice Unit (PPA) of Padang City Police should be given training in collaboration with the Ministry of Social Affairs in the framework of developing human resource competencies. It is better if the internal police regulations relating to the implementation of diversion are revised and adjusted to the applicable laws and regulations.
\end{abstract}

Keywords: Investigator; Diversion; Children; Padang City Police 


\section{Introduction}

A child is a creature created by God and is social beings. Since in the womb, children have the right to life, the right to independence the right to protection both from parents, family, community, nation and state (Abdussalam, 2007). Every child has the right to survival, growth and development and is entitled to protection from violence and discrimination (Law No. 35 of 2014).

Children are a national asset. As part of the young generation, children play a very strategic role as a nation's successor. In the Indonesian context, children are the successors to the ideals of the nation's struggle. This strategic role has been realized by the international community to give birth to an international convention that emphasizes the position of children as humans who must be protected and get protection for the rights they have (Achmad, 2005). Moreover, childhood is a period of sowing seeds, erection of piles, making the foundation of life which is called the formation of character, personality and character of a human person so that they will later have strength and ability and stand firm in their lives (Gultom, 2008).

In accordance with their nature, a child has a sense of reasoning that is not good enough to distinguish good from bad deeds. Crimes committed by children in general are the process of imitating or being influenced by adults. The formal criminal justice system which ultimately places children in prison status certainly has significant consequences in terms of child development. The process of law enforcement through the formal criminal justice system by putting children in prison apparently did not succeed in making children deterrent and become better individuals in supporting their growth and development process. Prisons often form more professional children in committing criminal acts (Joni \& Tanamas, 1999).

Therefore, it will be inversely proportional that the juvenile criminal justice process is not intended to meet the objectives of punishment comprehensively. Children cases are aimed at improving conditions, maintaining and protecting children and preventing constructive judicial actions (Prayitno, 2012). In essence, the court process is formed by the state to resolve the emergence of conflict and be neutral. However, the court is not the only way out to resolve the conflict. Conflict parties do not always use a settlement mechanism through litigation. It is the same as the case of children who are dealing with a law in which it is sought to be resolved through non-litigation way (Raharjo, 2011).

Therefore, in tackling irregularities in behavior or unlawful acts committed by children, it requires a special way of prevention and prevention for children by implementing the Criminal Justice System (SPPA). The aim is not merely to impose criminal sanctions on the child of a criminal offense but rather to focus on the premise that the imposition of criminal sanctions is a supporting means in realizing the welfare of the child of the criminal offender. According to Barda Nawawi Arief, the implementation of SPPA requires a special approach, special attention, special consideration, special care and treatment/ care as well as special protection for children dealing with law and justice. Through a special approach, children who commit crimes are seen as people who need help, understanding and affection. In addition, it prioritizes a persuasive-educative approach rather than a juridical approach which as far as possible avoids legal processes that are merely punitive, mental degradation and discouragement, as well as avoiding the process of stigmatization that can hinder the process of developing the maturity and independence of children in fair meaning (Barda Nawawi, 1992).

As a result, children who are detained or child convicts are forced to live in an area with adult prisoners, i.e. the Adult Penitentiary. These conditions have bad implications for child development. To avoid this and for the good of the child, law enforcers should make efforts to resolve cases of children in conflict with the law through a restorative justice approach carried out with the diversion process as stated in the Convention on the Rights of the Child, The Beijing Rules, and the Law No. 11 of 2012 concerning the Children Criminal Justice System (SPPA) Law. 
The presence of the SPPA Law does not mean that it has solved the problem of children in conflict with the law. This is evidenced by the many sentences of imprisonment to children compared to educative actions or better known as the double track system (Sholehuddin, 2003), namely returning the child to a parent or guardian, coaching by a foundation, or social department, and state-run care. Sentencing by the judge is not wrong but it is advisable for the judge to reconsider whether the sentence sentenced has provided protection for children and provides benefits.

The substance regulated in the SPPA Law is a form of protection for children in conflict with legal cases and children who are victims of criminal acts. Then, the most fundamental points in this Law are the explicit regulation of Restorative Justice and Diversion; i.e. a policy that is carried out to prevent perpetrators from the formal criminal justice system by involving victims, perpetrators, victims' families and perpetrators, the community, as well as stakeholders with a criminal act that occurs to reach agreement and resolution.

This effort is intended to avoid and keep children away from the judicial process so that stigmatization of children in conflict with the law can be avoided. Children are expected to return to the social environment naturally. This is in accordance with the provisions of Article 5 (1) and (3) of the SPPA Law which states that the Criminal Justice System must prioritize the Restorative Justice approach "and" in the juvenile justice system as referred to in paragraphs (2) letters a and b must seek diversion.

Related to this discretion, the authors made preliminary observations in the jurisdiction of Padang City Police where the crime committed by children increased from previous years. Preliminary data shows that criminal offenses committed by children with various activities indicate significant changes. Briptu Hary Chandra stated that the solution through diversion was greatly sought in handling cases of children with consideration for the best interests of children.

\section{Research Method}

Method is the process, principles, and procedures for solving a problem. Meanwhile, research is a careful, diligent and complete examination of a phenomenon to increase human knowledge. Thus, research methods can be interpreted as a process of principles and procedures for solving problems encountered in conducting research. ${ }^{1}$ The method that the researchers use is a sociological juridical approach; a research in the discipline of law is based on the reality that occurs in society where the type of study in this study is specifically more descriptive.

Primary data in this study were obtained through information or data directly obtained through field research conducted at Padang City Police. The primary data here is the results of observations made during the study and direct interviews with investigators at Padang City Police. In the selection of respondents, the writer employs the purposive sampling method, a method in which the respondent is determined deliberately by considering that the respondent is indeed the person who best understands the problem or experiences the problem to be investigated. Secondary data comes from secondary data sources or not directly obtained data but this data supports the discussion of this research. ${ }^{2}$ Secondary data here are documents or files in Padang City Police, books, scientific works and everything related to this research.

\footnotetext{
${ }^{1}$ Soerjono Soekanto, Introduction to Legal Research, Jakarta, UI Press, 1986, page 6.

${ }^{2}$ Sugiyono, Quantitative and Qualitative Research Methods, Bandung, Alfabeta, 2008, page 2.
} 
In order to obtain data that is appropriate and that covers the problem under research, this paper uses data collection techniques that include interviews, document studies, and observations. The data analysis technique in this research is qualitative analysis. According to Soejono Soekanto, qualitative analysis is a research method that produces descriptive analysis data; i.e. what is stated by the respondent in writing as well as verbally and the real behavior is also examined as something whole. ${ }^{3}$ Qualitative data analysis is a way of elaborating data based on field findings and literature studies. In this case, all data collected will be processed and analyzed by checking and editing all data collected through documentation, interview and observation techniques by correcting them one by one so that accurate data is obtained. When there is incorrect data, it will be corrected. After that, the classification of the data is carried out then the data is processed by compiling it in accordance with the formulation of the problem. Thus, it will show the results of all the problems to be examined. After the data is obtained and processed in the above manner, they will then be analyzed based on the theory used in this thesis.

\section{Discussion}

The Role of Investigators of the Protection Unit for Women and Children as a Criminal Justice SubSystem in Implementing Diversion of Children in Conflict with Law in the Jurisdiction of Padang City Police

Criminal justice in Indonesia is held by criminal justice institutions; i.e. Police, Prosecutors' Court, and Correctional Institution (LP). These judicial institutions are interconnected with each other in handling cases. According to Mardjono, the criminal justice system is a crime control system consisting of the Police, Attorney General's Office, and Correctional Institutions. Meanwhile, the objectives of the Criminal Justice System (SPP) according to Mardjono are: a) preventing the community from becoming victims of crime, b) resolving criminal cases that occur so that the community is satisfied that justice has been upheld and the guilty will be convicted, c) making sure that those who are have committed a crime not to commit a crime again (Afiah, 1986).

The relationship between the Police and the Court can be seen in the case of investigators requesting or submitting requests for an extension of detention, requesting a search, seizure and letter examination. Meanwhile, the relationship between the investigator and the judge can be seen during the trial before the trial. If in a trial the judge considers that the indictment made by the public prosecutor is not/ less true, the judge can provide an opportunity for the public prosecutor to improve it. In terms of relations with correctional institutions, the public prosecutor is the person assigned to carry out court decisions that have permanent legal force by including the person or defendant in the Correctional Institution (Hamzah, 2008). In Indonesia, the police monopolize the general criminal investigation (Criminal Code) which is different from other countries. Moreover, Indonesian society is a plural society that has different customs (Waluyo, 2004).

In the investigation process by the police, the investigator takes a series of actions needed to obtain evidence that will later be submitted as evidence. If the evidence is insufficient or the incident turns out not to be a criminal event or an invalid investigation by law, the investigator is authorized to stop the investigation process. Vice versa, if the evidence has been fulfilled and the incident is a criminal offense, the investigator will continue the investigation process to completion and make the minutes (filing the case) which is then submitted to the public prosecutor (Hamzah, 1987).

\footnotetext{
${ }^{3}$ Ibid, page 250 .
} 
In conducting an examination or investigation of a naughty child or a child who commits a crime, the investigator must pay attention to the following matters (Hartono, 2010). Investigators are required to examine the suspect in a family situation. In conducting investigations on naughty children, investigators are obliged to ask for protection or advice from the social counselor, and can seek consideration or advice from education experts, mental health experts if necessary. In addition, the investigation process of juvenile delinquency cases must be kept confidential.

The law has formulated that investigators conduct special investigations on naughty children. Thus, child investigators have the scope of duties in conducting investigations in accordance with the provisions of Article 1 No. 2 of the Criminal Procedure Code (Nashriana, 2011). At the investigation level, the investigator is also entitled to a diversion approach. The purpose of diversion is (Article 6 of the Child Protection Law):

a. to prevent children from detention;

b. to avoid labeling children as criminals;

c. to prevent the repetition of criminal acts committed by children;

d. to make children responsible for their actions;

e. to intervene as needed for victims and children without having to go through a formal process;

f. to prevent children from following the justice system process;

g. to keep children away from the influence and negative implications of the judicial process.

From an interview with AKP Edriyan Wiguna, Head of the Padang City Police Criminal Investigation Unit (4 June 2018), about the role of investigators in the protection unit for women and children in applying diversion to children in conflict with the law in the jurisdiction of Padang City Police, explaining that the police are the guards leader in law enforcement has a responsibility large enough to synergize the duties and authority of the Police of the Republic of Indonesia as stipulated in the Police Law of the Republic of Indonesia. In dealing with children in conflict with the law, the police must always pay attention to the condition of children who are different from adults.

Based on data in the field that the author obtained through interviews with Iptu Rozsa Rezkyfebrian, Head of PPA Unit Padang City Police (4 June 2018), he explained that crimes committed by children have increasingly diverse cases. The diversion of cases is in accordance with developments in the community and family environment of the child. Crimes committed by children and those that received complaints reports to Padang City Police were 35 (twenty-five) criminal cases. The criminal cases up to this thesis were made with the following details: in 2015, criminal cases committed by children were 10 (ten) cases, 2016 was 11 (twelve) cases, and 2017 was 11 (eleven) a case handled by the Padang City Police PPA Unit. There were 14 (fourteen) cases that were successfully resolved through diversion throughout 2015-2017. 
Table 1. Data on Children Cases at Padang City Police in 2015

\begin{tabular}{|c|c|c|c|c|c|}
\hline No. & Date & Name & Address & Case & Description \\
\hline 1 & 18 January & M. F & Tabing, Padang & Sexual abuse & $\begin{array}{l}\text { Issuance of Notification of } \\
\text { Commencement of } \\
\text { Investigation and P-21 } \\
\text { (Notice that the Investigation } \\
\text { Results are Complete) }\end{array}$ \\
\hline 2 & 24 February & D.S & Pampangan Lubeg, Padang & Rape & - \\
\hline 3 & 11 March & R.K & Gg Lok, Pampanga & Sexual abuse & $\begin{array}{c}\text { The suspect is on the People } \\
\text { Search List }\end{array}$ \\
\hline 4 & 10 April & F.I & $\begin{array}{c}\text { Koto Baru, Banuaran, Lubeg, } \\
\text { Padang }\end{array}$ & $\begin{array}{c}170 \text { jo } 351 \\
\text { Criminal Code }\end{array}$ & - \\
\hline 5 & 18 April & V.K & H. Agus Salim Sports Center & Sexual abuse & $\begin{array}{c}\text { Revoked } \\
\text { Counseling }\end{array}$ \\
\hline 6 & 18 May & D.S & $\begin{array}{c}\text { Car Workshop Warehouse } \\
\text { Intersection }\end{array}$ & $\begin{array}{c}\text { Criminal Code } \\
332 \\
\end{array}$ & Revoked \\
\hline 7 & 28 July & R.N & Bukik Koran, Padang & $\begin{array}{c}\text { Criminal Code } \\
310\end{array}$ & Revoked \\
\hline 8 & 20 September & E.A.D & Siteba, Padang & Rape & - \\
\hline 9 & 1 November & L.A & Gia Intersection, Padang & Embezzlement & Revoked \\
\hline 10 & 25 December & D.D & Volcano, Padang & $\begin{array}{l}\text { Criminal Code } \\
351\end{array}$ & Revoked \\
\hline \multicolumn{6}{|c|}{ Total Cases: 10 (ten) cases } \\
\hline
\end{tabular}

Table 2. Data on Children Cases at Padang City Police in 2016

\begin{tabular}{|c|c|c|c|c|c|}
\hline No. & Date & Name & Address & Case & Description \\
\hline 1 & 15 February & F.N & Seberang Padang & Criminal Code 351 & - \\
\hline 2 & 5 March & A.E & Air Pacah, Padang & Criminal Code 351 & Revoked \\
\hline 3 & 3 April & M.R.M & $\begin{array}{c}\text { Mata Air, P. Selatan District, } \\
\text { Padang }\end{array}$ & $\begin{array}{c}\text { Sexual abuse to the } \\
\text { same sex }\end{array}$ & Revoked \\
\hline 4 & 7 April & D.A & $\begin{array}{c}\text { Pulau Air Street, P. Selatan } \\
\text { Disctrict }\end{array}$ & Sexual abuse & Preliminary \\
Investigation
\end{tabular}




\begin{tabular}{|c|c|c|c|c|c|}
\hline 9 & 11 July & R.K & Lubuk Buaya, Padang & Sexual abuse & $\begin{array}{c}\text { The suspect is on the } \\
\text { People Search List }\end{array}$ \\
\hline 10 & 10 August & F.K & Koto Baru, Banuaran, & $\begin{array}{c}\text { Criminal Code } 170 \\
\text { and 351 }\end{array}$ & - \\
\hline 11 & 18 September & V.K & Kalumbuk,Padang & Sexual abuse & Revoked Counseling \\
\hline \multicolumn{7}{|r|}{ Total Cases: 11 (eleven) cases } \\
\hline
\end{tabular}

Table 3. Data on Children Cases at Padang City Police in 2016

\begin{tabular}{|c|c|c|c|c|c|}
\hline No. & Date & Name & Address & Case & Description \\
\hline 1 & 28 January & RR & Bukik Koran, Padang & Criminal Code 310 & Revoked \\
\hline 2 & 20 February & D.A & Lubuk Begalaung & Rape & Revoked \\
\hline 3 & 1 May & KA & Gia Intersection - Tabing, & Embezzlement & Revoked \\
\hline 4 & 10 July & AA & Azizi, Padang & Criminal Code 351 & Revoked \\
\hline 5 & 3 September & M.R & Lubuk Buaya, Padang & Criminal Code 359 & P 21 \\
\hline 6 & 20 September & M.Y & P. Barat District, Padang & Sexual abuse & Revoked \\
\hline 7 & 20 October & P.R.S & Parak Laweh,Padang & Criminal Code 332 & - \\
\hline 8 & 23 October & P.A.Y & Bunga Mas, Belimbing & Article 170 of Criminal & Revoked \\
\hline 9 & 7 November & I.R & Alang Laweh Lua & Sexual abuse & Investigation \\
\hline 10 & 19 November & N.H.I & Anak Air, Padang & Common Theft & Investigation \\
\hline 11 & 24 November & P.T & RT 01/ RW 11, Padang & Common Theft & Revoked \\
\hline 12 & 26 November & A.F & Padang Sarai, Padang & Motor Vehicle Theft & - \\
\hline 13 & 29 November & J.K & Melayu Village, Padang & Persecution 351 KUHP & - \\
\hline 14 & 20 December & O.L & Kuranji, Padang & Rape & Revoked \\
\hline & & & Total Cases: 14 (fourteen) cases & \multicolumn{2}{|c|}{} \\
\hline
\end{tabular}

Table 4. Diversion Conducted by the Padang City Police PPA Criminal Investigation Unit

\begin{tabular}{|c|c|c|c|}
\hline No. & Year & Number of Diversions & Description \\
\hline 1 & 2015 & 5 Cases & $\begin{array}{c}4 \text { Revoked } \\
1 \text { Revoked and Counseling }\end{array}$ \\
\hline 2 & 2016 & 3 Cases & $\begin{array}{c}\text { 2 Revoked } \\
1 \text { Revoked and Counseling }\end{array}$ \\
\hline 3 & 2017 & 8 Cases & 8 Revoked \\
\hline \multicolumn{2}{|c}{ Total Cases: 16 (sixteen) cases } \\
\hline
\end{tabular}


Based on the above table, it was concluded that there were 5 cases of diversion in 2015 with information of 4 revoked and 1 case of revoked and counseling. In 2016, there were 3 cases of diversion, 2 revoked and 1 revoked and counseling. In 2017, there was an increase in cases in Padang City against the number of diversions that occurred in Padang City Police as many as 8 cases of diversion in which 8 (eight) were revoked.

Based on the results of an interview between the author and Aipda Eja Basri, Head of PPA Sub Unit I of Padang City Police (June 4, 2018), in dealing with children as perpetrators of crime, investigators must take careful action. It means that if a case committed by a child is still classified as a minor act, it is not necessary to carry out an act of detention. Meanwhile, if the case is classified as a serious crime then detention can be carried out.

Children's rights in the process of investigation that are technical and tactic. The making of Minutes of Case (BAP) is very different from the BAP of adults. The suspect must be accompanied by their parents even though their legal advisor did not come to accompany the suspect. Here it is clearly illustrated that the role of parents is very significant. In addition, BAPAS (Penitentiary) also has a very important role, where in the inspection stage, BAPAS is obliged to assist the suspect, because BAPAS will provide more explanation to the suspect and what are the rights of the suspect when the examination takes place. BAPAS will also oversee the fulfillment of the rights of the suspect.

The consideration of the investigators not to detain a child who has been arrested is because the child is still in school or the crime is relatively mild with the value of losses that are not heavy or the child is the first time to commit a crime and is still a school student. Thus, against the child offender who fulfills the element of consideration, the action taken is verbal warning or the need to make a statement in front of the police so as not to repeat the crime again.

Based on the author's interview with Brigadier Heru Santoso, Bintara PPA Unit of Padang City Police (June 7, 2018), he explained that the process of examining child suspects was part of an investigative activity aimed at obtaining information, clarity and identities of the suspect and the evidence. It also requires special abilities that must be possessed by the examiner so that the treatment of child suspects must be distinguished from the treatment of adult suspects.

Based on the author's interview with AKP Edriyan Wiguna, Head of the Criminal Investigation Unit of Padang City Police (4 June 2018), the examination of child suspects in the jurisdiction of Padang City Police was carried out in a special room. The author's analysis indicates that the room is quite safe because it is in a room equipped with an air conditioner which is expected that the examination of the child can be carried out in a cool and comfortable atmosphere. In order to reflect the family situation in carrying out examination of children who are in conflict with the law, one of the efforts taken is to use facilities that can make the child not feel afraid. Next, members of the PPA Unit of the Criminal Investigation Unit of Padang City Police are as follows:

a. The Head of the Criminal Investigation Unit is A.K.P Eriyan Wiguna S.I.K;

b. Head of PPA Unit is Iptu Rozsa Rezkyfebrian S.I.K;

c. Head of Sub Unit I is Aipda Eja Basri SH;

d. Head of Sub Unit II is Bripkas Tovja SH;

e. Bintara Unit is Briptu Hary Chandra;

f. Bintara Unit is Bripda Cyndhanita Sukmana. P;

g. Bintara Unit is Brigadir Heru Santoso; and

h. Bintara Unit is Bripda Yuli Dastuti A.Md. 
Implementation of Diversion Conducted by the Protection Unit of Women and Children Against Children in Conflict with Law in the Jurisdiction of Padang City Police

Based on an interview with Iptu Rozsa Rezkyfebrian, Head of PPA Unit of Padang City Police, (4 June 2018), the resolution of child crime through diversion has implications for the role of investigators in dealing with child crime according to Law No. 11 of 2012 concerning the Children's Criminal Justice System. If the investigator's role in applying diversion to the children offender is explored in greater depth, then the investigator's role in the diversion process is as a mediator.

The role of the investigator has not been completed after the diversion agreement was concluded. Investigators will make a report on the agreed version of the diversion along with the minutes of the diversion. The investigator submits the report and minutes of the diversion agreement to the head of the District Court in accordance with its jurisdiction and the results of the agreement is determined by the Head of the District Court. Determination of the diversion agreement is notified to the investigator and submitted to the social supervisor. After receiving the stipulation of the diversion agreement, the investigator issues a letter stipulating the termination of the investigation of the criminal case.

Monitoring of the diversion process and the implementation of the agreements produced is handled by the direct supervisor of the official responsible at each level of examination. In other words, at the investigation level, the act of monitoring the diversion process and its implementation is the investigator's obligation. This has also been confirmed in Article 14 paragraph (1) of Law No. 11 of 2012 concerning the Juvenile Justice System which states that monitoring of the diversion process and the implementation of the resulting agreements are handled by the direct supervisor of the officials responsible at each level of examination.

Iptu Rozsa Rezkyfebrian stated that the diversion in the SPPA Law has been formulated in Chapter II which contains the requirements, implementation and what must be considered in the diversion. Diversion has several objectives in its implementation that are regulated in Article 6 of the SPPA Law, and it is carried out by the Padang City Police PPA unit, including the following:

a. Achieving peace between victims and children;

b. Settling cases of children outside the judicial process;

c. Avoiding children from deprivation of independence;

d. Encouraging society to participate; and

e. Instilling a sense of responsibility to the child.

The definition of diversion in Article 1 No. 7 of the SPPA Law is the transfer of the settlement of a child case from a criminal justice process to a process outside of criminal justice. Implementation of diversion uses a restorative approach. Based on article 5 paragraph (1) of the SPPA Law, the juvenile justice system must prioritize a restorative justice approach. Restorative justice according to Article 1 No. 6 of the SPPA Law is the settlement of criminal cases involving perpetrators, victims, the families of the perpetrators/ victims, and other related parties to jointly seek a fair resolution by emphasizing restoration back to its original state and not retaliation.

AKP Edriyan Wiguna stated (4 June 201) that Article 7 Paragraph (1) of Law no. 11 of 2012 has stated that at the level of investigation, prosecution and examination of cases of Children in the District Court must seek diversion. In addition, based on Article 7 Paragraph (2) of the SPPA Law, diversion must be implemented in the case of a crime committed by a child: a. threatened with imprisonment of under 7 (seven) years and $b$. is not a repeat of a criminal offense. 
Attempts to diversify at the investigation level according to Article 14 Paragraph (1) Government Regulation No. 65 of 2015 must be conducted within a maximum period of 7 x 24 (seven times twentyfour) hours from the date the investigation began. The investigator notifies and offers to the child and/or parent/ guardian as well as the victim or child victim and/or parent/ guardian to resolve the case through diversion and that has been carried out by the Padang City Police PPA Unit. If the child and/or parent/ guardian, as well as the victim or child victim and/or parent/ guardian agree to conduct diversion, the investigator determines the date when the diversion consultation begins. The diversion process takes place within a maximum period of 30 (thirty) days from the date the diversion begins.

Based on interviews with Iptu Rozsa Rezkyfebrian, Head of the PPA Unit of Padang City Police (4 June 2018), the diversion deliberation was led by investigators as facilitators and community counselors as facilitator representatives. The diversion process is carried out through deliberations by involving children and their parents/ guardians, victims or child victims and/or parents/ guardians, community counselors, and professional social workers based on a restorative justice approach. The entire process of implementing the diversion is recorded in the minutes of the diversion. Further provisions regarding the procedure for implementing diversion at the investigation level are regulated in the Regulation of the Head of the Indonesian National Police.

Based on an interview with Brigadir Heru Santoso, Brigadir PPA Unit of Padang City Police (7 June 2018), if the diversion deliberation is not successful, the investigator sends the case file to the public prosecutor and continues the criminal justice process. However, if the diversion succeeds, the results are outlined in the diversion agreement. The results of the diversion agreement must be determined by the Chair of the District Court in the area where the case occurred or in the area where the diversion agreement was made. The diversion agreement is formulated in the diversion agreement signed by the child and/or parent/ guardian, investigator, and social adviser. The determination is carried out within a maximum period of 3 (three) days from the time the diversion agreement is received. Determination is conveyed to the social counselor, investigator, public prosecutor, or judge within a maximum of 3 (three) days from the date of stipulation. Upon receipt of the decision, the investigator issues the investigation termination determination or the public prosecutor issues the termination of the prosecution. The Chairperson of the District Court issues a decision on the diversion agreement and at the same time determines the status of the evidence within a maximum period of 3 (three) days from the date of receipt of the diversion agreement and the minutes of diversion. This determination shall be conveyed to the investigator and the social adviser within a maximum period of 3 (three) days from the date of stipulation.

\section{Regulatory Guidelines Used Regarding the Implementation of Diversion in Padang City Police}

According to the explanation of Iptu Rozsa Rezkyfebrian (4 June 2018), in implementing the diversion, Padang City Police used SPPA Law regulations and the instructions for implementing the diversion issued by the Head of the Criminal Investigation Agency of the Republic of Indonesia namely the Secret Telegram of the Head of the Criminal Investigation Agency of the Republic of Indonesia TR/1124XI/2006 and TR/395/DIT.VI/2008 concerning the implementation of diversion and restorative justice in handling child offenders' cases and fulfilling the best interests of children in child cases whether as perpetrators, victims or witnesses.

Furthermore, the Secret Telegram of the Head of the Criminal Investigation Agency of the Republic of Indonesia TR/1124XI/2006 and TR/395/DIT.VI/2008 is a directive from the leadership of the Indonesian Police to the police to implement diversion through the restorative justice approach. Padang City Police have not used the Republic of Indonesia Government Regulation No. 65 of 2015 concerning Guidelines for the Implementation of Diversity and Handling of Children Aged 12 (Twelve) Years as a 
guide for implementing diversion because there are no orders and no internal regulations have been issued from the Police of the Republic of Indonesia.

\section{Procedure (Stages) Prior to the Diversity Implementation}

Based on an interview with Bripda Yuli Dastuti, Brigadir Unit PPA of Padang City Police (4 June 2018), after being named a suspect, Padang City Police immediately made preparations for diversion. Diversion must take place no later than 7 days after the determination of the child as a suspect. Detention will be carried out for children who have committed crimes with threats of more than 7 years. Diversion must be performed no later than 7 days after the determination to be a suspect. Before diversion is carried out, the Padang City Police will call the parties in an invitation letter. The parties include parties from the Penitentiary (BAPAS), the suspect and the family, the victim or his family, community leaders, assistants and so forth.

Brigadier Heru Santoso, Brigadir Unit PPA of Padang City Police, through an interview with the author (4 June 2018), explained that before carrying out the diversion in Padang City Police investigators must consider several things as regulated in article 9 of the SPPA Law, among others:
a. Criminal category;
b. Age of child;
c. The results of community research from BAPAS; and
d. Support from family and community environment.

Requirements applied by Padang City Police for children who will conduct diversion deliberations are carried out if the crime committed by the child: a. threatened with imprisonment of under 7 (seven) years; and $b$. is not a repeat of a criminal offense. Before the deliberations are held, the parties will be invited to attend the meeting. If one party (especially the victim and BAPAS) is unable to attend, the Padang City Police will send an invitation a second time to notify the holding of the diversion deliberation. However, if the second summons party is not called back, then the diversion will not be held. As regulated in Article 13 of Law No. 11 of 2012, the juvenile criminal justice process continues in terms of: a. the diversion process did not produce an agreement; or $b$. the diversion agreement was not implemented.

\section{Implementation of Diversion to Children in Conflict with The Law as A Criminal Offender}

Based on the author's interview with Bripda Cyndhanita Sukmana P, Brigadir Unit PPA of Padang City Police (4 June 2018), the implementation of diversion in Padang City Police did not set specific criteria for child investigators. All investigators can be diversified facilitators and there are no specific criteria. The Head of the PPA Unit of Padang City Police stated that no special training was given to child investigators in the Padang City Police ranks, so that all investigators could become child investigators. This is different from the provisions in Article 26 paragraph (2) of Law No. 11 of 2012 which states that the investigation of the case of children is carried out by investigators who are determined based on the Decree of the Chief of the Indonesian National Police or other officials appointed by the Head of the Indonesian National Police. The examination of the victim's child or witness' child is carried out by the child investigator. The requirements to be determined as child investigators are as follows: a. experienced as an investigator; b. have interest, attention, dedication, and understand the problems of children; and c. has attended technical training on juvenile justice. 
For the coordination of children who are recidivists, there is no application of a specific method. The child is only asked if he/she has ever undergone diversion before. There is no database as a guide to see the data of children who have participated in diversions in Padang City Police and Sectoral Police in the Padang City Police neighborhood. During the diversion at Padang City Police, investigators used official attributes because these attributes were the daily uniforms used during work. Whereas Article 22 of Law No. 11 of 2012 regulates that investigators, public prosecutors, judges, counselors, community members, advocates or other legal aid providers, and other officers in examining the cases of child, child victims, and/or child witnesses do not use official gowns or attributes.

Implementation of diversion in Padang City Police uses the restorative justice approach set out in Article 1 No. 6 of the SPPA Law. There are several forms of agreement on the diversion that occurred at Padang City Police as regulated in Article 11 of the SPPA Law, including the following:

a) peace with or without compensation;

b) submission to parents/ guardians;

c) participation in education or training in educational institutions or Social Welfare Organizations for a maximum of 3 (three) months; or

d) society service.

The coordination between the police and the prosecutor is carried out by sending a file when the diversion has been declared a failure and proceeding to prosecution. After the diversionary meeting reaches an agreement, the investigator submits the minutes of the diversion along with the agreement of the diversion to the head of the district court so that the determination is made as regulated in Article 29 paragraph (3) of the SPPA Law. If the diversion fails, the investigator is obliged to continue the investigation and submit the case to the public prosecutor by attaching the minutes of the diversion and social research report as regulated in Article 29 paragraph (4) of the SPPA Law.

\section{Obstacles to Investigators of the Women's and Child Protection Unit in Applying Diversion to Children in Conflict with the Law in the Jurisdiction of Padang City Police}

The process of examining a child suspect is part of an investigative activity which aims to obtain the information, clarity and identity of the suspect and the evidence. The examiner must also have special abilities so that the treatment given to children must be distinguished from adult suspects. The inspection process must be carried out by upholding the applicable law and always paying attention to human rights as stipulated in the Criminal Procedure Code.

In accordance with the results of an interview with Iptu Rozsa Rezkyfebrian, he stated that children's rights in the investigation process are technical and tactic. BAP (Minutes of Examination) children are different from adults. Thus, there are several obstacles that later child investigators will encounter in the examination process.

According to the author's point of view when conducting field research on criminal offenses the suspect is a child, several obstacles during the investigation process at the Padang City Police Office were divided into 2 (two) factors including:

\section{a. Internal Factor}

Based on interviews between the author and PAY family (June 8, 2018), in the investigation process, the suspect must be accompanied by his/her biological parents, legal counsel for the child 
suspects, and BAPAS (The Penitentiary) to ensure the fulfillment of the protection of children's rights in the investigation process. In this process the child suspect is examined in the room of the Woman and Children Waiting Unit (PPA) examining the suspect which enables the implementation of the inspection process in order to uncover the investigation of the case.

Furthermore, based on the results of an interview between the author and the OL family (June 10, 2018), the constraints that occur in this internal factor include: a) the constraints on legal counsel, legal counsel against child suspects often does not accompany their clients when the police make Minutes of Investigation of criminal offenses committed by children and b) during detention in Padang City Police Prison, these child suspects are sometimes joined with adult detention where the child suspect often gets abusive treatment from adult prisoners.

\section{b. External Factor}

1) In the process of investigation, the child is sometimes just silent and not speak clearly so that it is difficult for investigators in the investigation stage.

2) When delivering the rights of suspects, suspects and parents sometimes do not understand what protection is because there are a number of suspects who come from families who have not attended school.

3) During the investigation process, the suspect's parents sometimes scold the suspect, making the suspect feel cornered and do not want to talk.

4) At the time of detention there were several suspects in the detention cell who cried continuously and did not want to eat and sometimes the child behaved strangely. It is possible that this happened because the child felt guilty and was afraid of the threat of punishment that would be imposed on him/her when the judge sentenced him/her in a district court.

Based on an interview with Bripda Yuli Dastuti, Brigadir Unit PPA of Padang City Police (June 8, 2018), efforts made by the Padang City Police PPA investigators to overcome the obstacles that arise in upholding children' rights in the process of educating children suspect are:

a) If the legal counsel of the suspect cannot be present, the child PPA investigator will continue to ensure that the rights to the child suspect are fulfilled and this has been notified to each PPA investigator.

b) Related to the detention of a child suspect who is likened to an adult suspect, the Padang City Police will convey it to the West Sumatra Regional Police to allocate funds to build a special detention place for a wider child suspect.

c) During the investigation process, so that the child suspect does not remain silent, the investigator does a number of things, namely: 1) not using official attributes, 2) not yelling at the child, 3) making the surrounding conditions more comfortable, 4) providing facilities that make the suspect child feel comfortable

d) Regarding the suspect and the suspect's family who lack understanding about protection, the investigator will sometimes help the suspect and the suspect's family understand what protection is by giving examples of forms of protection.

e) Regarding parents who scold victims, investigators sometimes try to hold back the anger of the suspect's parents so as not to scold the suspect.

In implementing the diversion program, Padang City Police investigators faced several obstacles, for instance: victims felt their rights were not protected because the suspect was given privileges in the legal process. There is also the victim or the family considers the law to be biased and partial to the suspect. Reasons like this result in the failure of a discussion of diversion. 
In implementing the diversion at Padang City Police, no specific criteria were applied for child investigators. This can be an obstacle in implementing diversion. If the investigator is not equipped with competency as a child investigator, the investigator who in this case is a facilitator will not play an active role in the success of the diversion. The absence of one of the parties invited to the diversion deliberation became an obstacle in the diversion process at Padang City Police.

The success of the diversion deliberation at Padang City Police occurred because of an agreement, as stated in article 11 of the SPPA Law. The results of the diversion agreement can take the form of:

a) peace with or without compensation;

b) submission to parents/ guardians;

c) participation in education or training in educational institutions or Social Welfare Organizations for a maximum of 3 (three) months; or

d) community service.

Diversion can be successful if the suspect agrees to meet the requirements desired by the victim/ reporter and these requirements do not conflict with the law, religion, or propriety of the local society. Padang City Police has a strategy so that the victims or their families want to resolve the case through a diversion deliberation or agree to stop the investigation with several agreements. Child investigators (facilitators), BAPAS, the accompanying parties explain that there will be a bad effect on child offenders if they continue to follow the formal justice process and that deliberations should be carried out in a family way to achieve the path of peace.

\section{Conclusions}

Based on the analysis and explanation described in the previous sections, it is concluded that:

1. In applying diversion to children in conflict with the law in the jurisdiction of Padang City Police, the role of investigators for the Protection Unit for Women and Children is in accordance with the guidelines used which include the SPPA Law, Secret Telegram Head of the Criminal Investigation Agency of the Republic of Indonesia TR/1124/XI/2006 and TR/395/DIT.VI/2008, and Government Regulation No. 65 of 2015 as a guideline for implementing diversion. Implementation of diversion in Padang City Police is in accordance with the Law on the Juvenile Justice System.

2. Implementation of diversion by the Women's and Child Protection Unit for children in conflict with the law in the Padang City Police jurisdiction has been going well where there were 14 (fourteen) cases that were successfully resolved through diversion in 2015-2017.

3. There are obstacles that the Women and Child Protection Unit Investigators experience in applying diversion to children in conflict with the law in the jurisdiction of Padang City Police. For instance, the victim feels that his/her rights are not protected because the suspect is given privileges in the legal process. In addition, the victim or the family believes that the law is biased and partial to the suspect. This kind of reasons result in the failure of diversion deliberation. 


\section{References}

Books

Abdussalam. (2007). Hukum Perlindungan Anak. Jakarta: Restu Agung.

Achmad, R. (2005). Upaya Penyelesaian Masalah Anak Yang Berkonflik Dengan Hukum Di Kota Palembang. Simbur Cahaya, 27.

Afiah, N.A. (1986). Praperadilan dan Ruang Lingkupnya, Jakarta, CV. Akademika pressindo. Bandung: Alumni.

Barda Nawawi, A. (1992). Bunga Rampai Kebijakan Hukum Pidana.

Gultom, M. (2014). Perlindungan Hukum Terhadap Anak dalam Sistem Peradilan Pidana Anak di Indonesia. Refika Aditama.

Hamzah, A. (2008). Hukum Acara Pidana Indonesia, Jakarta, Sinar Grafika.

Hamzah, A. 1987.Pengantar Hukum Acara Pidana Indonesia, Jakarta: Ghalia Indonesia,.

Hartono. (2010). Penyidikan dan Penegakan Hukum Pidana Melalui Pendekatan Progresif, Jakarta: Sinar Grafika.

Joni, M., \& Tanamas, Z. Z. (1999). Aspek Hukum Perlindungan Anak dalam Perspektif Konvensi Hak Anak. Citra Aditya Bakti.

Nashriana. (2011). Perlindungan Hukum Pidana Bagi Anak di Indonesia, Jakarta, PT.Raja Grfindo Persada.

Prayitno, D. (2012). Wajah Hukum Asas dan Perkembangan, Bekasi: Gratama Publishing.

Raharjo, T. (2011). Mediasi pidana dalam sistem peradilan pidana: suatu kajian perbandingan dan penerapannya di Indonesia. Buku Litera.

Sholehuddin, M. (2003). Sistem sanksi dalam hukum pidana: Ide dasar double track system \& implementasinya. Divisi Buku Perguruan Tinggi, RajaGrafindo Persada.

Waluyo, B. (2004). Pidana dan Pemidanaan, Jakarta: Sinar Grafika.

\section{Legislation}

The 1945 Constitution of the Republic of Indonesia.

Law No. 1 of 1946 concerning the Criminal Law Regulations (Criminal Code).

Law No. 8 of 1981 concerning the Criminal Procedure Code.

Law No. 39 of 1999 concerning Human Rights.

Law No. 11 of 2012 concerning Criminal Justice System for Children.

Law No.17 of 2016 Second Amendment to Law No. 23 of 2002 concerning Child Protection. 
Regulation of the Chief of Police of the Republic of Indonesia, Police Number 10 of 2007 concerning the Organization and Work Procedure of the Women's and Children's Services Unit.

Government Regulation of the Republic of Indonesia No. 65 of 2015 concerning Guidelines for the Implementation of Diversity and Handling of Children Under 12 (Twelve) Years.

Secret Telegram of the Head of the Criminal Detective Agency Police Number: TR/1124/xi/2006.

Internet

Adrianus Meliala, Penerapan Diskresi Kepolisian dalam Penegakan Hukum Pidana, http://digilib.unila.ac.id/29462/3/TESIS\%20TANPA\%20BAB\%20PEMBAHASAN.pdf, diakses pada tanggal 20 Mei 2018.

http://geotimes.co.id/indonesia-butuh-tambahan-lapas-khusus-anak/, diakses pada 25 Oktober 2016.

http://www.solopos.com/2016/01/25/perlindungan-anak-kasus-anak-berhadapan-hukum-kian-banyak-inikata-mendikbud-684467, diakses pada 20 Oktober 2016.

http://www.antaranews.com/berita/460372/70-ribu-anak-dihukum-di-lp-umum, diakses pada 13 Februari 2016.

Zamidi, Diskresi Kepolisian, http://digilib.unila.ac.id/534/7/BAB\%20II.pdf, dikases pada tanggal 21 Mei 2018.

\section{Copyrights}

Copyright for this article is retained by the author(s), with first publication rights granted to the journal.

This is an open-access article distributed under the terms and conditions of the Creative Commons Attribution license (http://creativecommons.org/licenses/by/4.0/). 